\title{
River channel width controls blocking by slow-moving landslides in California's Franciscan mélange
}

\author{
Noah J. Finnegan ${ }^{1}$, Kiara N. Broudy ${ }^{1}$, Alexander L. Nereson ${ }^{1}$, Joshua J. Roering ${ }^{2}$, \\ Alexander L. Handwerger ${ }^{3}$, and Georgina Bennett ${ }^{4}$ \\ ${ }^{1}$ Department of Earth and Planetary Sciences, UC Santa Cruz, Santa Cruz, CA 95064, USA \\ ${ }^{2}$ Department of Earth Sciences, University of Oregon, Eugene, OR 97403, USA \\ ${ }^{3}$ Jet Propulsion Laboratory, California Institute of Technology, Pasadena, CA 91109, USA \\ ${ }^{4}$ School of Environmental Sciences, University of East Anglia, Norwich, Norfolk, NR4 7TJ, UK \\ Correspondence: Noah J. Finnegan (nfinnega@ucsc.edu)
}

Received: 1 October 2018 - Discussion started: 18 October 2018

Revised: 26 July 2019 - Accepted: 12 August 2019 - Published: 20 September 2019

\begin{abstract}
To explore the sensitivity of rivers to blocking from landslide debris, we exploit two similar geomorphic settings in California's Franciscan mélange where slow-moving landslides, often referred to as earthflows, impinge on river channels with drainage areas that differ by a factor of 30. Analysis of valley widths and river long profiles over $\sim 19 \mathrm{~km}$ of Alameda Creek $\left(185 \mathrm{~km}^{2}\right.$ drainage area) and Arroyo Hondo $\left(200 \mathrm{~km}^{2}\right.$ drainage area) in central California shows a very consistent picture in which earthflows that intersect these channels force tens of meters of gravel aggradation for kilometers upstream, leading to apparently long-lived sediment storage and channel burial at these sites. In contrast, over a $\sim 30 \mathrm{~km}$ section of the Eel River $\left(5547 \mathrm{~km}^{2}\right.$ drainage area), there are no knickpoints or aggradation upstream of locations where earthflows impinge on its channel. Hydraulic and hydrologic data from United States Geological Survey (USGS) gages on Arroyo Hondo and the Eel River, combined with measured size distributions of boulders input by landslides for both locations, suggest that landslide derived boulders are not mobile at either site during the largest floods ( $>2$-year recurrence) with field-measured flow depths. We therefore argue that boulder transport capacity is an unlikely explanation for the observed difference in sensitivity to landslide inputs. At the same time, we find that earthflow fluxes per unit channel width are nearly identical for Oak Ridge earthflow on Arroyo Hondo, where evidence for blocking is clear, and for the Boulder Creek earthflow on the Eel River, where evidence for blocking is absent. These observations suggest that boulder supply is also an unlikely explanation for the observed morphological differences along the two rivers. Instead, we argue that the dramatically different sensitivity of the two locations to landslide blocking is related to differences in channel width relative to typical seasonal displacements of earthflows. A synthesis of seasonal earthflow displacements in the Franciscan mélange shows that the channel width of the Eel River is $\sim 5$ times larger than the largest annual seasonal displacement. In contrast, during wet winters, earthflows are capable of crossing the entire channel width of Arroyo Hondo and Alameda Creek. In support of this interpretation, satellite imagery shows that immobile earthflow-derived boulders are generally confined to the edges of the channel on the Eel River. By contrast, immobile earthflow-derived boulders jam the entire channel on Arroyo Hondo. Our results imply that lower drainage area reaches of earthflow-dominated catchments may be particularly prone to blocking. By inhibiting the upstream propagation of base-level signals, valley-blocking earthflows may therefore promote the formation of so-called "relict topography".
\end{abstract}




\section{Introduction}

River incision into bedrock drives landscape change in unglaciated settings and is the key process linking tectonics and topography (Whipple, 2004). However, the process of river incision is sensitive to the amount and caliber of coarse sediment supplied from hillslopes (Sklar and Dietrich, 2001, 2004) such that coarse sediment input can accelerate (Cook et al., 2013) or arrest incision (Bull, 1990). This non-linearity reflects the dual role of coarse sediment in providing abrasive tools and inhibiting incision when deposited on the bed (Gilbert, 1877).

The dependence of river incision on hillslope-derived coarse sediment input also means that river incision, which provides the lower boundary condition for hillslopes, and landsliding, which delivers coarse sediment to channels, are coupled (Golly et al., 2017; Ouimet et al., 2007; Schuerch et al., 2006). The apparent strength of this coupling, however, varies widely. On the one hand, river aggradation and valley blockages triggered by rockfalls and rock avalanches can persist for timescales as long as $10^{4}$ years (Korup et al., 2006). Similarly, elevated coarse sediment loads following co-seismic landslides can attenuate over timescales as long as centuries (Stolle et al., 2019; Yanites et al., 2010). These examples suggest that landsliding provides a strong negative feedback on river incision by causing long-lived burial events and hence hiatuses in downcutting (Miller et al., 2016; Ouimet et al., 2007; Yanites et al., 2010). These examples also suggest that valley aggradation or incision following a landslide may occur long after evidence for the landslide itself is recognizable in the landscape. On the other hand, in some settings, little evidence of valley blocking is seen despite extremely high rates of landsliding (Korup et al., 2010), suggesting a contrasting view in which rivers are not strongly perturbed following landslides and in which landsliding occurs essentially passively in response to river incision (Burbank et al., 1996; Larsen and Montgomery, 2012).

Work devoted to the problem of landslide dam formation from the perspective of landslide processes emphasizes both the rates of material delivery to channels as well as the width of river valleys into which debris is delivered as key controls on dam formation (Costa and Schuster, 1988; Korup, 2002). That said, comparatively less work has focused on fluvial controls on the resilience of rivers to landslide inputs. With this in mind, here we explore what governs river resilience to valley blocking by landslide debris. Towards this end, we exploit two similar geomorphic settings in the California Coast Range where slow-moving landslides, often referred to as earthflows, impinge on river channels with drainage areas that differ by a factor of 30 . By comparing mapped landslide locations to long profile and valley morphology, we establish locations where valley blocking from earthflows has occurred at each site. We then explore factors that govern apparent contrasts in river resilience to valley blocking in otherwise similar geomorphic and geologic settings.
In this paper, we consciously use the term valley blocking instead of damming. While valley blocking from earthflows, like damming, can cause aggradation for kilometers upstream to depths of several tens of meters, it is unusual that earthflows deposit sediment rapidly enough to cause the formation of lakes. Hence, to avoid confusion, here we adopt the term valley blocking.

\section{Geologic and geomorphic setting}

The Franciscan Complex is an assemblage of variably deformed and metamorphosed rock units formed in a subduction zone during the Mesozoic and early Cenozoic eras (Wakabayashi, 1992). With widespread occurrence throughout the state of California (Fig. 1), Franciscan lithologies include primarily detrital sedimentary rocks such as sandstones and argillaceous mélanges that are well known for their low strength and high susceptibility to slope failure. Many documented instances of earthflows, in particular, in California occur within these units (Iverson and Major, 1987; Keefer and Johnson, 1983; Kelsey, 1978; Roering et al., 2015; Scheingross et al., 2013). Earthflows are characterized by a flow-like appearance and persistent motion over decades to centuries (Hungr et al., 2014). They form above fine-grained bedrock in plastic, clayey soil and are commonly large $(>500 \mathrm{~m}$ long) and deep $(>5 \mathrm{~m})$. They typically move at rates less than $\sim 10 \mathrm{~m} \mathrm{yr}^{-1}$ (Baum et al., 2003); however, they can also display more rapid but short-lived surge-like events approaching $\sim \mathrm{m} \mathrm{d}^{-1}$ (Hungr et al., 2014). Active earthflows frequently extend from ridge tops to valley bottoms (Mackey and Roering, 2011) and are classically described as having an "hourglass" planform outline, with a bowl-shaped source area, an elongated transport zone and a lobate toe (Keefer and Johnson, 1983). Notwithstanding their name and appearance, most earthflow movement occurs by sliding along discrete basal and lateral shear surfaces (Fleming and Johnson, 1989; Keefer and Johnson, 1983; Simoni et al., 2013; Vulliet and Hutter, 1988; Zhang et al., 1991). In this paper, we exploit two locations in the California Coast Range where earthflows impinge on channels of greatly differing scale. Both of these locations are underlain by Franciscan Complex lithologic units. Below, we describe each location separately.

\subsection{Arroyo Hondo and Alameda Creek}

Arroyo Hondo $\left(200 \mathrm{~km}^{2}\right)$ and upper Alameda Creek $\left(185 \mathrm{~km}^{2}\right)$ drain a rugged region of the northern Diablo Range, northeast of San Jose, California (Figs. 1 and 2). Their confluence occurs just downstream of Calaveras Dam, which impounds Calaveras Reservoir, the largest reservoir in the San Francisco Bay Area. Where each creek crosses the actively uplifting Diablo Range, it has incised a deep $(\sim 600 \mathrm{~m})$ canyon into Franciscan formation sandstone and mudstone mélange. The walls of these canyons are draped 


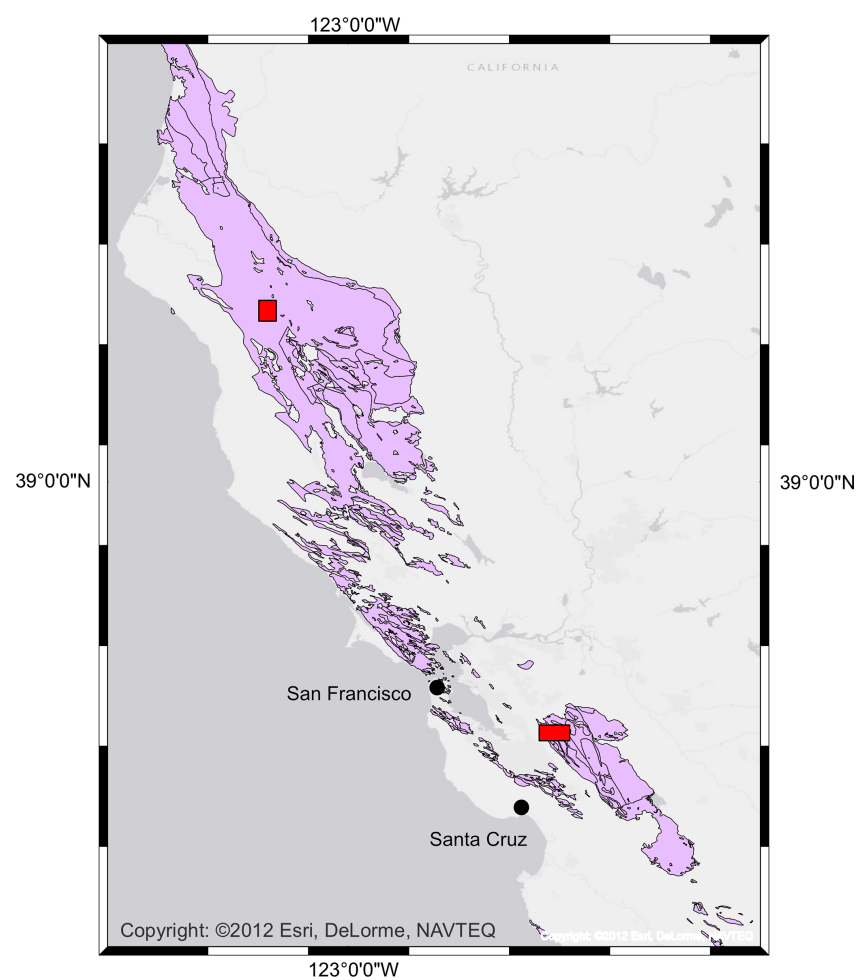

Figure 1. Overview of the study region. Franciscan Complex rocks are shown in purple. Red boxes indicate the locations of the two field locales.

with earthflows (Figs. 2 and 3). One of them, Oak Ridge earthflow, was studied by Nereson and Finnegan (2019), who analyzed its historical motion from aerial photos that span 1937-2017. Within the persistently active $\sim 100 \mathrm{~m}$ wide transport zone of the earthflow, the mean velocity was $\sim 2.15 \mathrm{~m} \mathrm{yr}^{-1}$ over this time interval (Nereson and Finnegan, 2019). We use field observations and detailed measurements of boulder size distributions at Oak Ridge earthflow as a reference site from which we make more generalized inferences about the relationship between earthflows and valley blocking in Alameda Creek and Arroyo Hondo. Here, we analyze approximately $11 \mathrm{~km}$ of Alameda Creek and $8 \mathrm{~km}$ of Arroyo Hondo. These are reaches where the authors have performed extensive field reconnaissance. A United States Geological Survey (USGS) gage on Arroyo Hondo is located within the study section considered here (https://waterdata. usgs.gov/usa/nwis/uv?11173200, last access: 23 July 2018) (Fig. 2). At this location, Arroyo Hondo has a drainage area of $200 \mathrm{~km}^{2}$. Annual rainfall at Oak Ridge earthflow is $53 \mathrm{~cm}$, most of which occurs between October and May (Nereson and Finnegan, 2019).

\subsection{Eel River}

We also exploit a study site developed by Mackey and Roering (2011) along a $\sim 30 \mathrm{~km}$ section of the main stem Eel

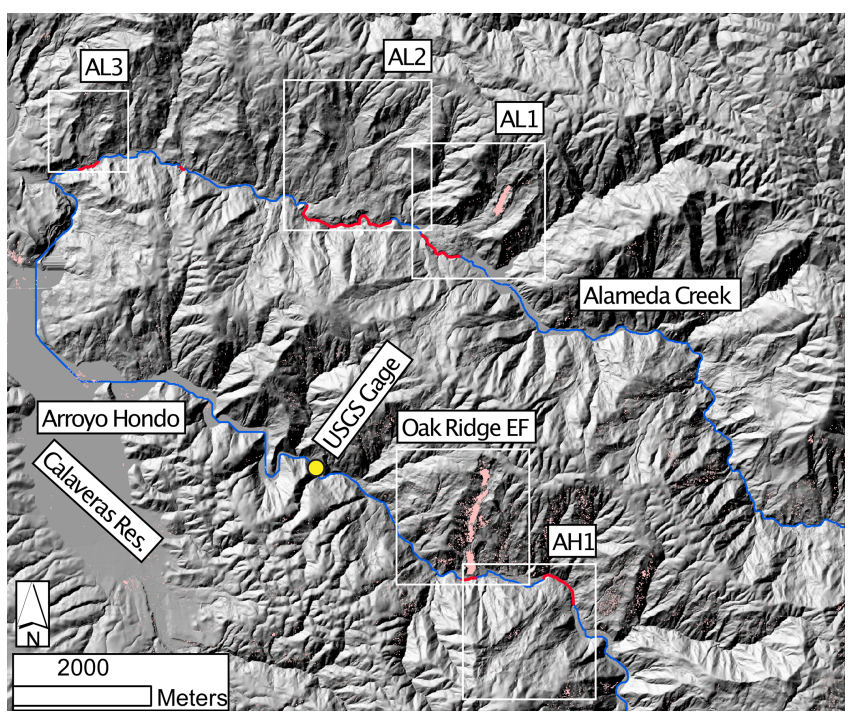

Figure 2. Shaded relief map of the study reaches of the Alameda Creek and Arroyo Hondo watersheds. White boxes highlight large mapped earthflows in the study area, which are shown in more detail in Fig. 3. Rivers channels are indicated with blue lines, except where they intersect active earthflows (red lines). Areas of light red shading show regions where the InSAR analysis indicated line-ofsite velocities in excess of $3 \mathrm{~cm} \mathrm{yr}^{-1}$.

River between Dos Rios and Alderpoint (Figs. 1 and 4) in the northern California Coast Range in Mendocino, Humboldt and Trinity counties. At this location, the Eel River cuts an $\sim 800 \mathrm{~m}$ deep canyon into actively uplifting rocks of the Central Belt of the Franciscan Complex (McLaughlin et al., 2000). The Central Belt consists of mudstone mélange, similar to Arroyo Hondo and Alameda Creek, that surrounds coherent blocks of various lithologies that can be as large as entire mountains (Roering et al., 2015). At this location, Mackey and Roering (2011) tracked the historical motion of 122 earthflows from 1944 to 2006 . Over this period, the median annual sliding velocity of all landslides was $0.4 \mathrm{~m} \mathrm{yr}^{-1}$. More recent work (Bennett et al., 2016a) revealed a significant deceleration of these earthflows during the historic California drought from 2012-2015, and both recent acceleration and activation of new slides during the extremely wet winter of 2016-2017 (Handwerger et al., 2019a, b). We analyze river data from a USGS gage located at Fort Seward (https: //waterdata.usgs.gov/ca/nwis/uv?site_no $=11475000$, last access: 23 July 2018), approximately $12 \mathrm{~km}$ downstream of Alderpoint. At this location, the Eel River has a drainage area of $5547 \mathrm{~km}^{2}$. Because there are no major tributary junctions between the study reach and the Fort Seward gage, we assume the Fort Seward gage is approximately representative of the conditions within the study section. Annual rainfall at Alderpoint is $130 \mathrm{~cm}$ (Mackey and Roering, 2011). We use a reference site at an active earthflow, referred to as the "Mile 201" slide by Mackey and Roering (2011), just down- 

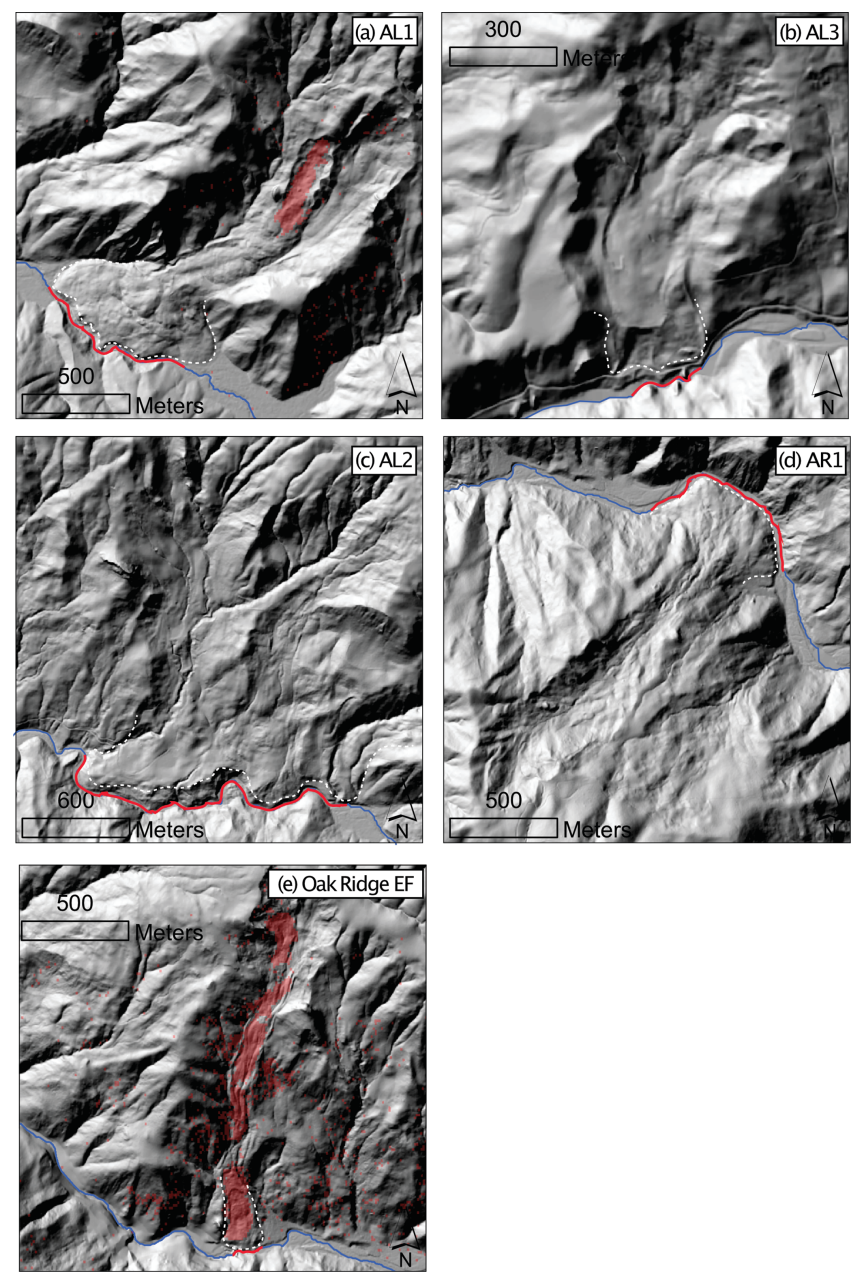

Figure 3. Shaded relief maps of three large earthflows on Alameda Creek (a-c) and two on Arroyo Hondo (d-e). Dashed white lines indicate the mapped edge of earthflow toes, and red lines indicate where river channels (shown in blue) intersect earthflows. Areas of red shading show regions where the InSAR analysis indicated lineof-site velocities in excess of $3 \mathrm{~cm} \mathrm{yr}^{-1}$.

stream from the confluence of Kekawaka Creek with the Eel River (Fig. 4). At this location, we make detailed measurements of boulder size distributions being supplied to the Eel River by earthflows via high-resolution aerial imagery.

\section{Methods}

\subsection{Landslide impacts on channels}

We use river long profile morphology (along with floodplain width, described below) to assess the fluvial response to earthflow inputs. Earthflow deposits are commonly comprised of large boulders, which can lead to steep boulder cascades downstream of landslide blockages and in turn drive fluvial aggradation upstream (Kelsey, 1978). Thus, the topographic signature of valley-blocking landslides in river long

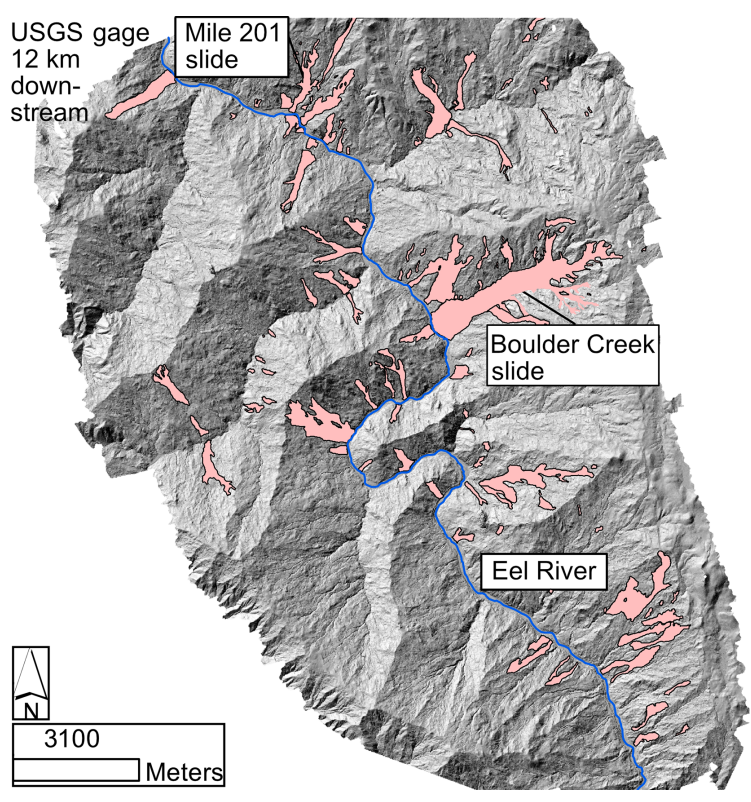

Figure 4. Shaded relief map of the Eel River site. The thalweg of the Eel River is shown in blue. Areas of red shading are active earthflows mapped by Mackey and Roering (2011). River flow is from the lower right to upper left.

profiles is an anomalously low-gradient reach, representing the upstream aggradational section, that grades downstream to the lip of a steep knickpoint, which represents the valleyblocking deposit (Ouimet et al., 2007). To highlight such reaches, we linearly detrend the river long profiles for each of the three reaches examined. The residual topography following detrending highlights locations where the channel departs from a smoothly graded profile. In addition, the amplitude of the residual topography provides a direct measurement of the height of valley blockages and hence the depth of fluvial aggradation upstream of blockages.

Valley aggradation in a steep-walled canyon leads naturally to floodplain widening simply by virtue of the triangular cross-section of a valley (Mey et al., 2015; Reneau and Dietrich, 1991). For this reason, we also make measurements of local floodplain width to complement our channel slope measurements. The logic here is that deep aggradation upstream of landslide blockages should be reflected in local floodplain width. We use lidar-derived slope maps to help identify the slope break that marks the intersection of the steep canyon wall with the low-gradient valley bottom alluvial deposits. We hand digitized a line corresponding to this slope break along each side of the three canyon reaches examined here. We then rasterized this line and used ArcGIS to calculate the Euclidean distance from both the right and left edges of the floodplain. The sum of these Euclidean distance maps within the active floodplain yields an approximation of the local floodplain width, which we extract at each point where we measure elevation. To highlight poten- 
tially landslide-impacted river reaches, we look for points that mark rapid changes in valley width (from wide to narrow) and rapid changes in river slope (from low to high).

For both sites, we take advantage of lidar-derived topography data to make measurements of river channel morphology. For the Eel River site, we use lidar data as described by Mackey and Roering (2011). For the Alameda Creek/Arroyo Hondo site, we use one-ninth second USGS NED data. We hand digitized thalweg profiles for both study locations using shaded relief maps. We extracted elevation points every $100 \mathrm{~m}$ for the Eel River and every $10 \mathrm{~m}$ for the Arroyo Hondo and Alameda Creek sites. This difference in spacing reflects the approximate difference in channel width for the two locations.

\subsection{Quantification of boulder size distributions}

We use Google Earth imagery, which we exported to ArcGIS after re-georeferencing, to map boulder size distributions entering channels at the toes of active earthflows at our two reference sites. The toe of Oak Ridge earthflow is currently collapsing along a series of rotational failures into Arroyo Hondo (Nereson and Finnegan, 2019), which, in combination with prehistoric motion of the earthflow toe, has resulted in an accumulation of large, unsorted earthflow-derived boulders in the channel of Arroyo Hondo at the base of the earthflow. We digitized all visible boulders $(n=329)$ as ellipses, which we then fit with rectangles to quantify the major and minor axis lengths of the boulders. The imagery enables us to identify boulders down to $30 \mathrm{~cm}$ in diameter. Because of the proximity of boulders to the earthflow toe and the absence of sorting in the field, we treat the distribution of boulders at the toe of Oak Ridge earthflow as representative of the coarse fraction of material (larger than the $30 \mathrm{~cm}$ detection limit) that is eroding out of the earthflow once its fine matrix has been winnowed away (e.g., Kelsey, 1978). This interpretation is supported by the fact that it is impossible to differentiate individual grains on bar surfaces upstream of the earthflow toe in aerial imagery. In other words, the bulk of the distribution of bedload that is moved by the river appears to fall below the detection limit in the aerial imagery.

For the Eel River reference site, we divided the channel into three domains where we digitized boulders separately. Along the north (river right) bank of the Eel River at the toe of the Mile 201 slide is an accumulation of unsorted boulders similar to what is observed at Arroyo Hondo along the toe of Oak Ridge. However, in contrast to the Arroyo Hondo reference site, within the thalweg of the Eel River, large boulders are absent and weak sorting is apparent. Hence, we treat the population of boulders along the north bank $(n=413)$ as representative of the coarse fraction $(>30 \mathrm{~cm})$ that is eroding out of the mélange that comprises the body of the Mile 201 earthflow, whereas we consider the thalweg to be more influenced by fluvial transport. The south (river left) bank of the Eel River at this site is similar to the north bank. However, we treat the distribution of boulders from this site $(n=706)$ separately because we are unsure whether this material is sourced from the Mile 201 slide or the active earthflow that enters this same location from the south (Mackey and Roering, 2011). Like in Arroyo Hondo, it is impossible to differentiate individual grains on bar surfaces away from earthflow toes in aerial imagery. Hence, again, we assume that most of the distribution of bedload that is moved by the river appears to fall below the detection limit in the imagery.

\subsection{Hydrology}

The USGS gage on Arroyo Hondo is located within the study reach, roughly $2 \mathrm{~km}$ downstream of Oak Ridge earthflow. The gage record includes 36 years of annual peak flood measurements and 248 field measurements of discharge, width and cross-sectional area during both high- and low-flow events. The USGS gage on the Eel River is located approximately $25 \mathrm{~km}$ downstream of the Highway 201 slide and roughly $12 \mathrm{~km}$ downstream of the edge of the lidar data considered here. The gage record includes 62 years of annual peak flood measurements and 364 field measurements of discharge, width and cross-sectional area during both high- and low-flow events.

We calculated the recurrence period associated with the annual peak flood measurements for each gage according to standard methods (Dunne and Leopold, 1978). We then estimated the magnitude of the 2-year recurrence interval flood from the record. To accomplish this, we located the recurrence intervals that bracketed 2 years in the record and fit a line between these two points. Finally, using linear interpolation, we determined the approximate magnitude of the 2year recurrence interval flood, which we use as a representative high-flow event in our analysis. In alluvial channels, the 2-year recurrence interval flood often corresponds to "bankfull" flow (Wolman and Miller, 1960). For this reason, the 2year flood is commonly interpreted as the "formative" flow with respect to bankfull hydraulic geometry. Here, we use the 2-year flood, however, simply as a representative flood event that would mobilize the bed in most self-formed alluvial channels but not necessarily in a channel overwhelmed with landslide debris.

Fortuitously, field measurements of discharge and hydraulic geometry for both gages bracket the 2-year recurrence interval flood. We divide measured cross-sectional area by width to quantify mean flow depth by assuming a rectangular geometry for each gage. We then plotted mean flow depth versus discharge for each record. The relationship between discharge and flow depth was well fit with a powerlaw relationship for the Eel River record. Hence, for this record, we simply use the best-fitting power-law relationship to find the mean depth associated with the 2-year recurrence interval flood, as well as for the maximum flood discharge during which field measurements were made. For Arroyo Hondo, a power law does not fit the relationship between dis- 
charge and flow depth at the discharge near the 2-year recurrence interval flood. Consequently, for this record, we used a linear fit for discharge greater than $20 \mathrm{~m}^{3} \mathrm{~s}^{-1}$, which fits the data well in this region. We then apply this linear fit in order to determine the mean flow depth associated with the 2-year recurrence interval flood on Arroyo Hondo, as well as for the maximum flood discharge during which field measurements were made.

\subsection{Landslide identification}

For the Eel River site, we use the landslide mapping of Mackey and Roering (2011), who identified 122 active individual earthflows within the Eel River study site using historical aerial photos (Fig. 4). More recent studies using optical images as well as satellite and airborne radar interferometry show that the majority of these landslides are still active (Bennett et al., 2016a, b; Handwerger et al., 2015, 2019b)

For Arroyo Hondo and Alameda Creek, we used a combination of airborne synthetic aperture radar interferometry (InSAR), lidar topography and field reconnaissance to identify slow landslides that are either currently active or have been active in the recent geomorphic past.

Based on our own field reconnaissance in the area, as well as through interpretation of lidar-derived topographic maps, we have identified several large earthflows within the field area that clearly impinge on the channels of Arroyo Hondo and Alameda Creek (Figs. 2 and 3). We also process radar interferometry data from the NASA/JPL airborne uninhabited aerial vehicle synthetic aperture radar (UAVSAR) platform to identify active landslides between 2009 and 2017 (Appendix A). UAVSAR operates with a L-band radar wavelength $(\sim 24 \mathrm{~cm})$ and collects data at this location approximately two times per year along track 23503 (aircraft moving at $230^{\circ}$ and looking at $140^{\circ}$ ). We processed 31 interferograms using the InSAR Scientific Computing Environment (ISCE) software package developed at JPL/Caltech and Stanford (Rosen et al., 2012). We remove topographic contributions to the phase using a $12 \mathrm{~m}$ digital elevation model (DEM) from the DLR TanDEM-X satellites. We also reduce InSAR phase noise using a standard power spectral filter with a value of 0.5 (Goldstein and Werner, 1998). Finally, we selected seven high-quality interferograms (i.e., minimal unwrapping errors, high coherence) to compute an average lineof-sight (LOS) velocity map for landslides within the study area.

\section{Results}

\subsection{Long profile and valley width}

Figures 5a, 6a and 7a show elevation long profiles of Arroyo Hondo, Alameda Creek and the Eel River, respectively. Also indicated on the figures are the locations where landslides intersect river channels, as shown in Figs. 2-4. For
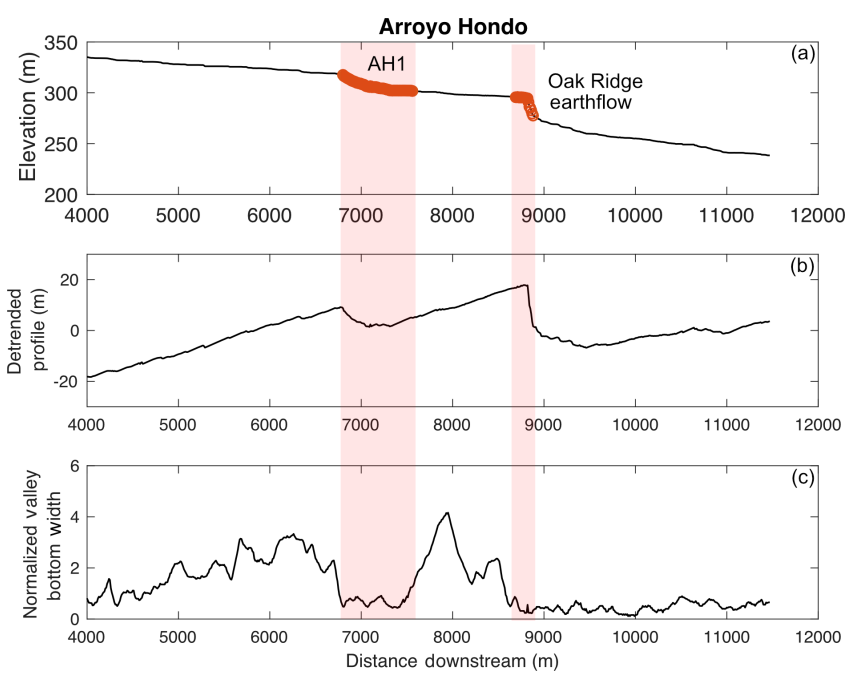

Figure 5. (a) Elevation long profile of Arroyo Hondo. Locations where the channel intersects mapped earthflows in Figs. 2 and 3 are shown in red and labeled. (b) Detrended elevation profile of Arroyo Hondo for the reach shown in panel (a). (c) Valley bottom width for Arroyo Hondo normalized by the mean valley bottom width over the reach shown in panel (a). In panels (a)-(c), the red boxes highlight earthflow-impacted reaches.
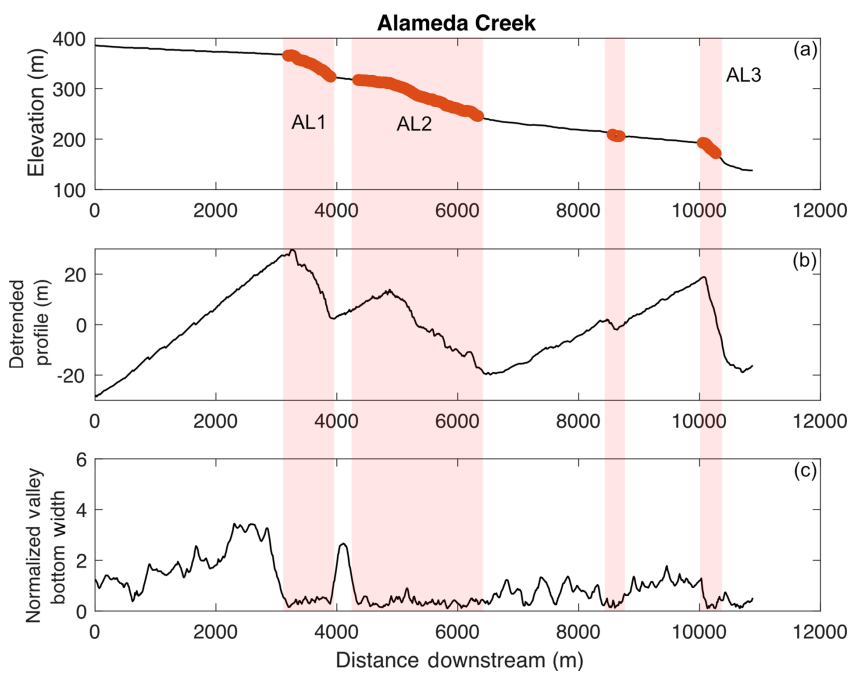

Figure 6. (a) Elevation long profile of Alameda Creek. Locations where the channel intersects mapped earthflows in Figs. 2 and 3 are shown in red and labeled. (b) Detrended elevation profile of Alameda Creek for the reach shown in panel (a). (c) Valley bottom width for Alameda Creek normalized by the mean valley bottom width over the reach shown in panel (a). In panels (a)-(c), the red boxes highlight earthflow-impacted reaches.

the Eel River, landslide locations come from Mackey and Roering (2011). For Alameda Creek, landslide locations are, again, based on a combination of field reconnaissance, lidar interpretation and InSAR. 


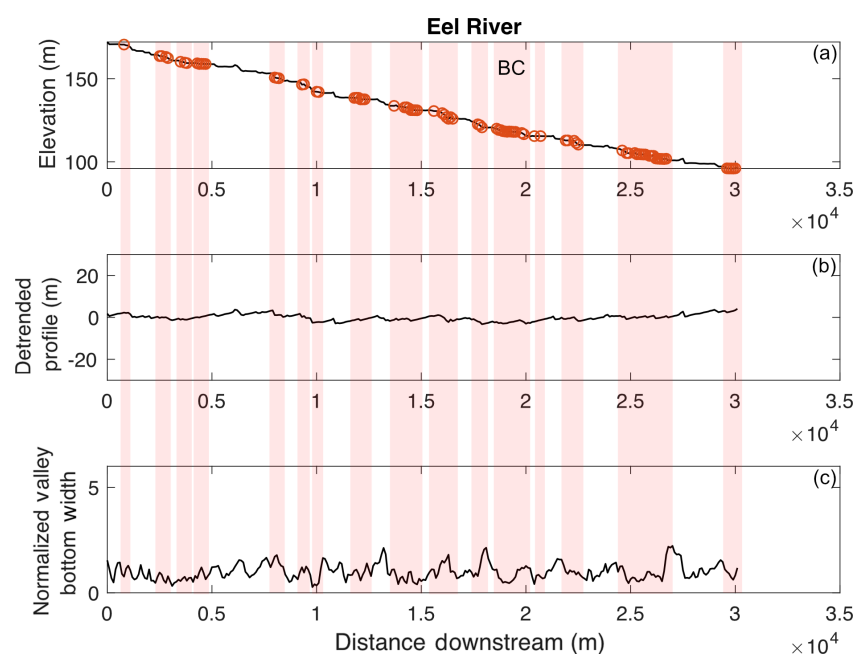

Figure 7. (a) Elevation long profile of the Eel River. Locations where the channel intersects mapped earthflows in Fig. 4 are shown in red. (b) Detrended elevation profile of the Eel River for the reach shown in panel (a). (c) Valley bottom width on the Eel River normalized by the mean valley bottom width over the reach shown in panel (a). Red rectangles highlight earthflow-impacted reaches in panels (a)-(c). BC indicates location of Boulder Creek earthflow.

Figures $5 \mathrm{~b}-\mathrm{c}$ and $6 \mathrm{~b}-\mathrm{c}$ show detrended long profiles and valley width (normalized to the mean for each river), respectively, for Alameda Creek and Arroyo Hondo. For both channels, mapped landslide locations coincide with locations along the river marked by rapid changes in valley width from wide upstream to narrow downstream and large steps in the elevation long profile that separate anomalously lowgradient reaches upstream from anomalously steep reaches downstream. We also note that the sharpest river slope increase associated with earthflows along Alameda Creek and Arroyo Hondo occurs at Oak Ridge earthflow, which is the only failure in the region that is both currently active and coupled to a river channel (Arroyo Hondo) according to InSAR (Figs. 2 and 3) and feature tracking (Nereson and Finnegan, 2019).

In contrast, Fig. $7 \mathrm{~b}-\mathrm{c}$ show that active landslides along the Eel River have no obvious impacts on long profile morphology and valley widths. At no location along the Eel River section is the amplitude of the detrended river elevation profile larger than the 2-year flow depth, suggesting that most of the residual elevation is related to gravel bars, which are abundant along the reach in question. In addition, except for one spot along the Eel River section, valley bottom width is always less than a factor of 2 greater than the mean.

\subsection{Boulder size distributions}

Figure 8 shows empirical cumulative distribution functions (CDFs) of the minor axis of boulders mapped at the toe of Oak Ridge earthflow, and for the right and left banks of the
Eel River at the toe of the Mile 201 slide. Although the distributions diverge below $\sim 1 \mathrm{~m}$, the curves are quite similar for boulders larger than $1 \mathrm{~m}$. A two-sample KolmogorovSmirnov test for the portions of each of the three measured boulder distributions above $1 \mathrm{~m}$ is unable to reject the hypothesis (at the $5 \%$ significance level) that the three boulder populations are drawn from the same distribution. For the Eel River, the median measured boulder size is $1.02 \mathrm{~m}$ and the 84th percentile is $1.90 \mathrm{~m}$. For Arroyo Hondo, the median measured boulder size is $0.82 \mathrm{~m}$ and the 84 th percentile is $1.83 \mathrm{~m}$.

\subsection{Hydrology}

Figures 9 and 10 show calculated mean flow depths based on field measurements of channel width and cross-sectional area for each gage. As noted earlier, the 2-year recurrence interval event (shown in red in each figure) falls within the range of field measurements for the two sites, making accurate interpolation of the characteristic 2-year recurrence interval depth straightforward. Table 1 reports both the 2-year and largest measured mean flood depths for each gage.

\subsection{Quantification of sediment size mobility threshold}

We rearrange the Shields equation to solve for the threshold gravel size that can be moved assuming all of the shear stress acting on the channel bed is available to transport sediment:

$D=\frac{\tau}{\left(\rho_{\mathrm{s}}-\rho\right) g \tau_{\mathrm{c}}^{*}}$.

In Eq. (1), $D$ represents gravel diameter, $\tau$ is the mean channel bed shear stress, $\rho$ and $\rho_{\mathrm{s}}$ are the density of water and sediment, respectively, $g$ is the acceleration due to gravity, and $\tau_{\mathrm{c}}^{*}$ is the critical Shields stress. $\tau$ is calculated via the depth slope product, $\rho g h s$, where $h$ is mean flow depth and $s$ is channel slope. For the Arroyo Hondo USGS gage, the threshold gravel diameter associated with a 2 -year flood is $0.31 \mathrm{~m}$. For the largest recorded flood at the gage, the threshold gravel diameter is $0.51 \mathrm{~m}$ (Fig. 8). For the Eel River gage, the threshold gravel diameter associated with a 2-year flood is $0.22 \mathrm{~m}$. For the largest recorded flood at the gage, the threshold gravel diameter is $0.32 \mathrm{~m}$ (Fig. 8).

We note that these estimates ignore the possible morphodynamic feedbacks that might result from the deposition of large boulders in a channel. On the one hand, landslide derived boulder deposits are steep relative to points upstream and downstream (Figs. 5a and 6b), suggesting that the deposition of landslide debris might lead to conditions more favorable to coarse sediment transport. On the other hand, large boulders exert substantial drag on the flow, which can completely offset increases in coarse sediment transport capacity due to the steeper slopes of boulder cascades (Schneider et al., 2016). For this reason, we simply consider the coarse sediment transport capacity of the river at the gage sites as an 


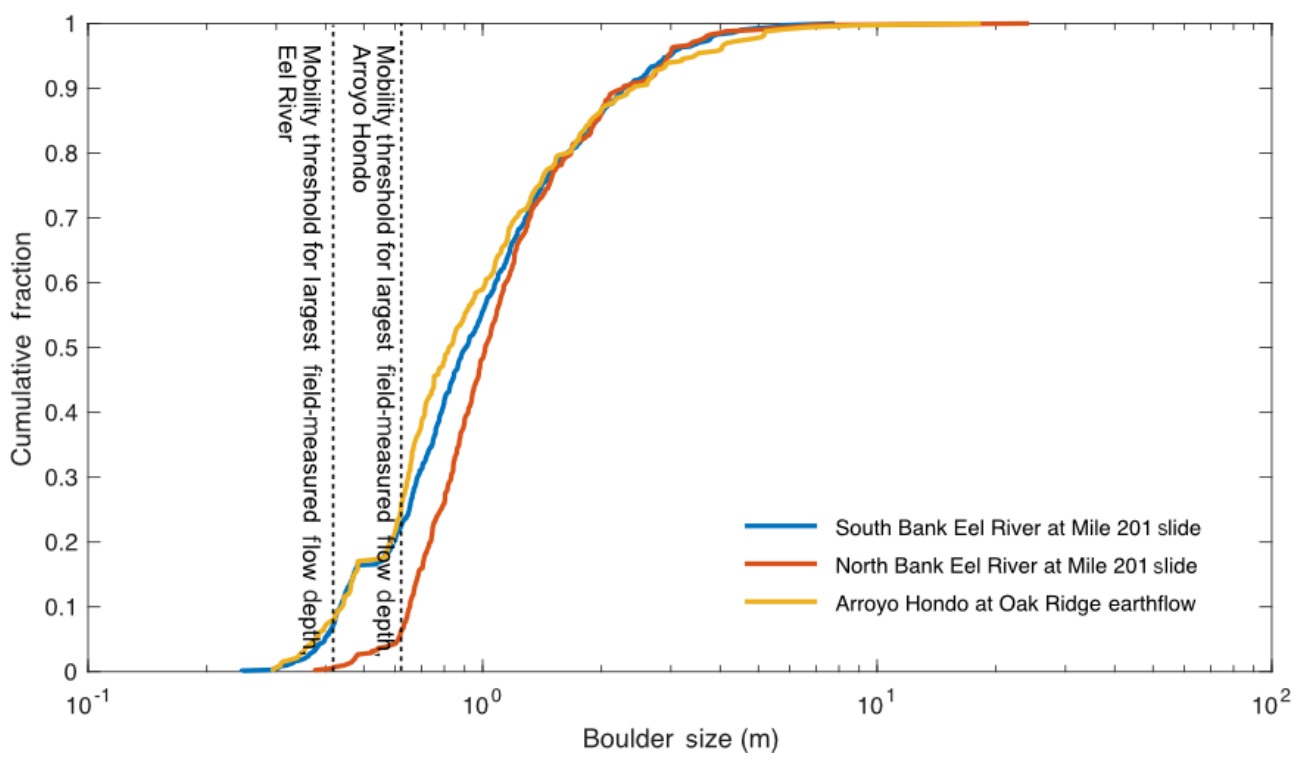

Figure 8. Empirical cumulative distribution functions for the minor axes of earthflow-derived boulders at the toe of Oak Ridge earthflow and for the banks of the Eel River site at the Mile 201 slide. The vertical lines indicate the threshold mobile grain diameter for the largest field-measured flow depths at each site (see Figs. 9 and 10).

Table 1. Channel characteristics for the two reference locations.

\begin{tabular}{lrrrrrrrr}
\hline & $\begin{array}{r}\text { 2-Year } \\
\text { mean flow } \\
\text { depth } \\
(\mathrm{m})\end{array}$ & $\begin{array}{r}\text { Largest field- } \\
\text { measured flow } \\
\text { mean depth } \\
(\mathrm{m})\end{array}$ & $\begin{array}{r}\text { Channel } \\
\text { slope }\end{array}$ & $\begin{array}{r}\text { 2-Year } \\
\text { mean bed } \\
\text { shear stress } \\
(\text { Pa) }\end{array}$ & $\begin{array}{r}\text { Largest field- } \\
\text { measured flow } \\
\text { mean bed } \\
\text { shear stress (Pa) }\end{array}$ & $\begin{array}{r}\text { 2-Year gravel } \\
\text { mobility } \\
\text { threshold } \\
(\mathrm{m})\end{array}$ & $\begin{array}{r}\text { Largest field- } \\
\text { measured } \\
\text { flow mobility } \\
\text { threshold (m) }\end{array}$ & $\begin{array}{r}\text { Channel } \\
\text { width } \\
(\mathrm{m})\end{array}$ \\
\hline Eel River & 7.1 & 10 & 0.0026 & 180 & 255 & 0.22 & 0.32 \\
Arroyo Hondo & 1.6 & 2.8 & 0.016 & 250 & 431 & 0.31 & 0.53 \\
\hline
\end{tabular}

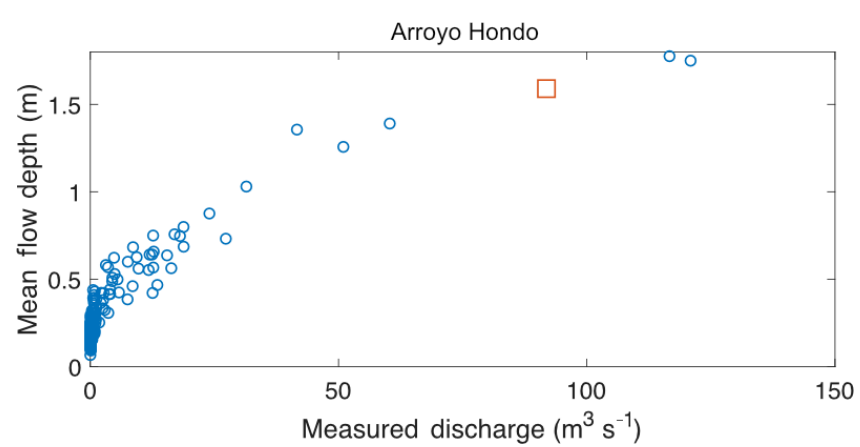

Figure 9. Mean flow depth versus measured discharge for the USGS Arroyo Hondo gage. Red square indicates the interpolated 2-year recurrence interval depth.

index of the river's ability to move coarse landslide-derived debris independent of changes in bed morphology caused by that debris.

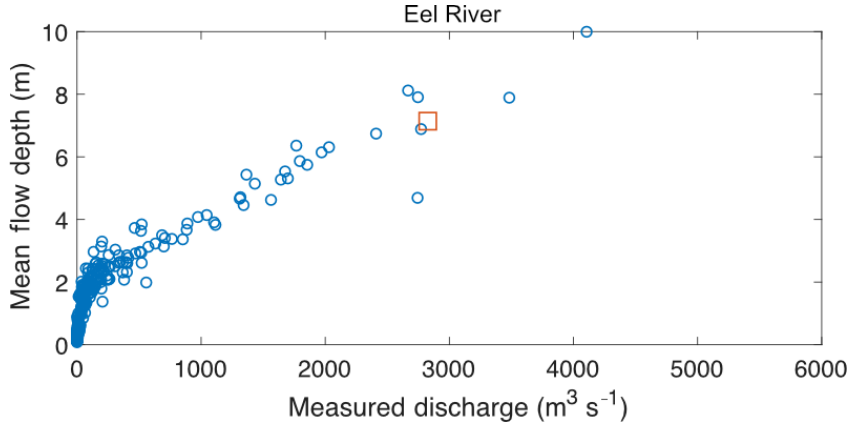

Figure 10. Mean flow depth versus measured discharge for the USGS Eel River gage at Fort Seward. Red square indicates the interpolated 2-year recurrence interval depth.

\section{Discussion and conclusions}

\subsection{What controls valley blocking?}

Analysis of valley widths and river long profiles in Alameda Creek and Arroyo Hondo shows a very consistent picture in which landslides that intersect the channel force tens of me- 
ters of gravel aggradation for kilometers upstream, leading to apparently long-lived sediment storage and channel burial at these sites (Figs. 5a-c and 6a-c). In contrast to Arroyo Hondo and Alameda Creek, the Eel River does not display knickpoints at or aggradation upstream of locations where earthflows impinge on the channel, such as at the Mile 201 slide (Fig. 7a-c). Because of the similar mass-wasting processes operating in the two study sites, we can identify no obvious explanation based on landslide processes alone for the paucity of evidence for valley blocking on the Eel River site. Indeed, all else being equal, we would expect more evidence for valley blocking at the Eel River site given the much greater density of active slow landslides there compared to the Arroyo Hondo and Alameda Creek sites. Given this apparently strong difference in the response of these two river systems to similar hillslope forcing, below we explore several potential explanations based on fluvial geomorphology for the apparent resilience of the Eel River site to valley blocking by slow landslides.

\subsection{Coarse sediment transport capacity}

The results of our gravel mobility calculations (Table 1) show that boulders delivered by earthflows should be immobile once delivered to river channels at both study locales. Only the very left tail of the size distribution of boulders approaches the threshold for gravel mobility in both channels during even the largest flood ( $>2$-year recurrence) for which field data exist at each gage (Fig. 8). That said, boulders are relatively more immobile for a given Shields stress compared to gravel (Prancevic and Lamb, 2015). Hence, it is entirely plausible that the entire distribution of boulder sizes delivered by earthflows is immobile once delivered to channels in both locations. This interpretation is supported by the fact that gravel bars downstream of the two reference earthflow sites do not contain boulders and typically do not contain clasts that are even discernable above the $\sim 30 \mathrm{~cm}$ resolution of the imagery. In addition, from examination of historical aerial photography in Google Earth for both locations, we were unable to see unambiguous evidence for mobile boulders even following very wet winters with large recorded flood events.

\subsection{Coarse sediment supply}

Given the relatively short time period covered by the gage data used in the mobility analysis, we acknowledge the possibility that large and infrequent floods move boulders over very long timescales (Cook et al., 2018). With this possibility in mind, here we consider landslide sediment supply relative to transport capacity as a potential driver of the differences in apparent sensitivity to landslide blocking observed between our two study sites. Because the Eel River is $\sim 10$ times wider than Arroyo Hondo, it has a much larger coarse sediment transport capacity than Arroyo Hondo just by virtue of its width. Hence, it is possible that the resilience of the Eel River to earthflow blocking is a consequence of its larger width and hence volumetric transport capacity. To test this, we used data from Mackey and Roering (2011) to calculate the volumetric sediment flux per unit river width of the Boulder Creek earthflow, which is the largest earthflow on the Eel River (Fig. 4). We compare this calculation to the volumetric flux per unit river width associated with Oak Ridge earthflow. The latter is calculated using the mean velocity of Oak Ridge earthflow $\left(2.15 \mathrm{~m} \mathrm{yr}^{-1}\right)$ (Nereson and Finnegan, 2019) multiplied by the width of the earthflow $(\sim 100 \mathrm{~m})$ and the depth $(\sim 8 \mathrm{~m})$, as reported from electrical resistivity surveys of the slide (Murphy et al., 2018). Although the Boulder Creek earthflow has an order of magnitude larger volumetric flux $\left(\sim 15000 \mathrm{~m}^{3} \mathrm{yr}^{-1}\right)$ than Oak Ridge earthflow $\left(\sim 1700 \mathrm{~m}^{3} \mathrm{yr}^{-1}\right)$, the Eel River has an order of magnitude larger channel width $(125 \mathrm{~m})$ than Arroyo Hondo $(12 \mathrm{~m})$. Hence, earthflow fluxes per unit channel width at the two sites are nearly identical: $\sim 140 \mathrm{~m}^{2} \mathrm{yr}^{-1}$ for Arroyo Hondo and $\sim 130 \mathrm{~m}^{2} \mathrm{yr}^{-1}$ for the Eel River. Assuming a similar concentration of boulders within the mélange at both sites, which is reasonable based on the surface distribution of boulders that is apparent at both sites, this calculation suggests that boulder fluxes per unit channel width at the two sites are also likely to be comparable. Despite this similarity, there is no evidence of blocking in the long profile of the Eel River at the location of the Boulder Creek slide ( $\sim$ km 18 in Fig. 7a), whereas the channel of Arroyo Hondo is clearly blocked at Oak Ridge (Fig. 5). For this reason, we also rule out boulder supply relative to transport capacity as a likely driver of the observed morphological differences on the two rivers.

\subsection{Channel width and seasonal earthflow displacement}

An alternative explanation for the resilience of the Eel River to landslide blocking may be related to differences in channel width at both sites relative to typical seasonal displacements of earthflows. Figure 11 shows a histogram of seasonal earthflow displacement in the Franciscan mélange from Nereson and Finnegan (2019), who used a physically based model to interpolate between 22 air photos of Oak Ridge earthflow, and Kelsey (1978), who used stakes to directly measure displacement on six earthflows in the Van Duzen River watershed, a tributary of the Eel River, in northern California between 1973 and 1976. Notably, the distribution of displacements, which is well fit with an exponential distribution with a mean annual displacement of $\sim 4 \mathrm{~m}$, contains the channel width of Arroyo Hondo (Fig. 11). By contrast, the channel width of the Eel River is $\sim 5$ times larger than the largest annual displacement in the distribution. Thus, during wet winters with large displacements, earthflows are capable of surging across the entire channel of Arroyo Hondo. In contrast, on the Eel River, large earthflow surges can impinge on but cannot cross the active channel. In support of this interpretation, satellite imagery shows that immobile earthflow- 


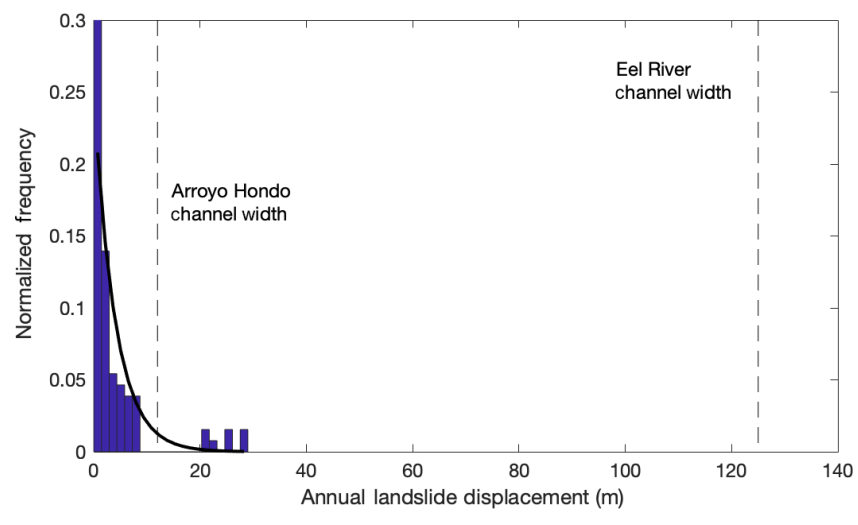

Figure 11. Normalized histogram of annual earthflow displacements in the Franciscan mélange; data are from Kelsey (1978) and Nereson and Finnegan (2019). Black line shows exponential fit between normalized frequency and displacement. Vertical dashed lines indicate the channel width of Arroyo Hondo and the Eel River.

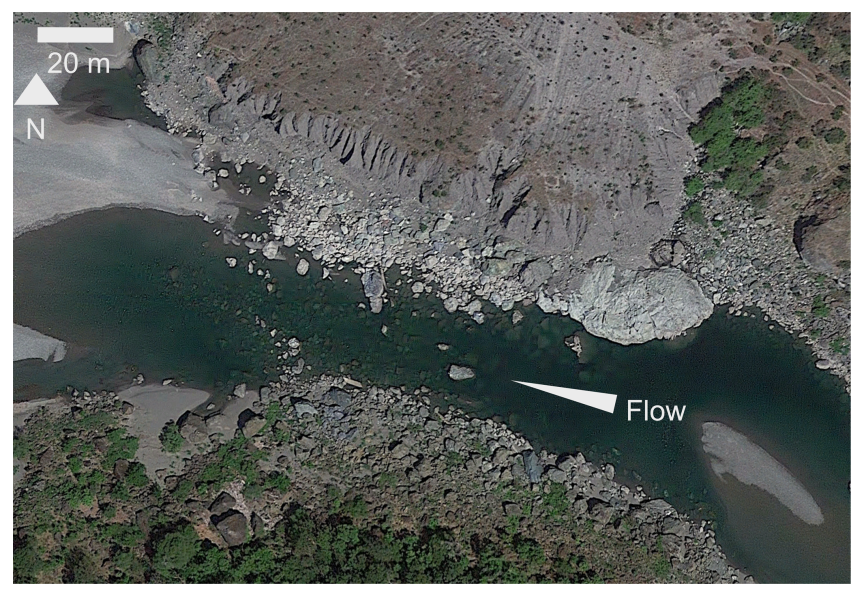

Figure 12. (C) Google Earth satellite image of the Eel River at the toe of the Mile 201 earthflow, 28 May 2014. Flow is from right to left, and north is up. Earthflows enter the channel here on each bank, which likely explains the different colored boulders being deposited on each bank.

derived boulders are generally confined to the edges of the channel on the Eel River (Fig. 12) where at each bank an active earthflow enters the Eel River. By contrast, immobile earthflow-derived boulders jam the entire channel on Arroyo Hondo (Fig. 13). We interpret this striking difference in channel morphology as an indication of the ability of earthflows to cross and hence deposit boulders within the entire width of Arroyo Hondo.

The contrasting long profile and channel morphology of the two reference locations thus suggests that the formation of valley blockages by earthflows is very sensitive to the width of river channels relative to the characteristic displacement of earthflows. In this way, channels where landslides can cross the channel may act like step-pool channels, where channel-spanning, landslide-derived boulder jams lo-

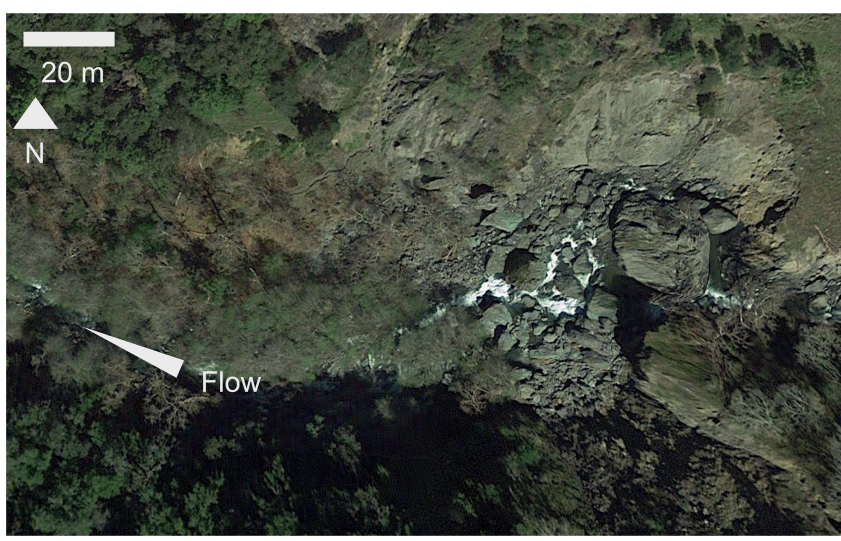

Figure 13. (C) Google Earth satellite image of Arroyo Hondo at the toe of the Oak Ridge earthflow during high-flow conditions, 11 March 2017. Flow is from right to left, and north is up.

cally impede coarse sediment transport. In support of this view, the observations of Golly et al. (2017) and Brummer and Montgomery (2006) directly linked channel-spanning boulder jams to channel-spanning landslides in two mountainous settings. According to flume experiments (Zimmermann et al., 2010), particle jams become much more likely when the channel width is less than 6 times the 84th percentile of the grain size distribution. Not coincidentally, bulk friction angle (and hence stability) of chains of clasts is larger for smaller chains, with an inflection in the relationship between frictional stability and number of clasts at around six grains (Booth et al., 2014). Notably, the ratio of channel width to the 84th percentile diameter of earthflow-derived boulders on Arroyo Hondo is $\sim 6$, suggesting that Arroyo Hondo and Alameda Creek are in a regime where they are much more susceptible to jamming once boulders are deposited on their beds. This interpretation also agrees with Costa and Schuster (1988), who found that valley width is a clear control on landslide dam formation because it is easier to block a narrow valley than a wide valley.

The fact that the Eel River does not show evidence for valley blocking likely reflects that fact that the channel is always able to flow around the toe of earthflows. In addition, the ratio of channel width to the 84th percentile diameter of earthflow-derived boulders on the Eel River is $\sim 65$, which is well beyond the threshold associated with jamming. That said, over their lifetimes, earthflows can travel hundreds of meters (Mackey and Roering, 2011; Nereson and Finnegan, 2019), distances that are in excess of what would be required to block the Eel River. Yet the Eel River shows no evidence for blocking; why? The matrix of earthflows in the Franciscan mélange is very fine grained, making it easily transported in suspension by rivers (Kelsey, 1978; Mackey and Roering, 2011). We speculate that short-lived advances of earthflows into the Eel River during wet winters are countered by the ability of the river to remove the matrix of the earthflow dur- 
ing subsequent years, leading to a relatively stable position of the earthflow toe relative to the channel despite long-term displacements that are sufficient to cross the channel. We emphasize, however, that this interpretation is only applicable to the relatively slow-moving earthflows that are plentiful in the Eel River basin. Catastrophic landslides, which can occur outside of the Franciscan mélange along the Eel River, have dammed the Eel River in at least one location during the Pleistocene, resulting in the formation of a landslidedammed lake (Mackey et al., 2011).

\subsection{Implications for river incision and landscape evolution}

The results of our analysis imply that the Eel River, and wide rivers like it, should be able to sustain vertical incision despite active earthflows. In other words, in settings where earthflow surges are small in comparison to channel width, landsliding may not represent a strong negative feedback on river incision. In contrast, in settings such as Arroyo Hondo and Alameda Creek, where surges can cross the entire channel, landsliding should represent a strong negative feedback on vertical river incision by triggering channelspanning boulder jams that force aggradation over large sections of river upstream of active landslides (Figs. 5a-c and 6a-c). Notably, this difference in sensitivity to landslide input is independent of the examined rivers' capacities to actually mobilize coarse debris.

Thus, our results imply that lower drainage area reaches of earthflow-dominated catchments may be particularly prone to blocking. By inhibiting the upstream propagation of baselevel signals, valley-blocking earthflows may therefore promote the formation of so-called "relict topography" (Clark et al., 2006; Schoenbohm et al., 2004), where the upper portions of watersheds are unable to incise at the same rate as the mainstream. Indeed, Bennett et al. (2016a) noted that tributaries to the Eel River are choked with coarse sediment that significantly impedes river incision into bedrock and hypothesized that earthflow-dominated catchments are prone to a so-called "landslide cover effect", which prevents or delays the upstream propagation of base-level signals, thereby leading to the formation of relict topography. Similarly, Korup et al. (2010) argued that sediment inputs from rockfalls and glaciers have suppressed river incision into the margin of the Tibetan Plateau, aiding in its apparent longevity. We note that Ouimet et al. (2007) and Shobe et al. (2016) also demonstrated a landslide cover effect via numerical modeling of bedrock river incision.

Our results are generally supportive of these perspectives and offer a simple mechanism for the instability that triggers the incisional shutdown of earthflow-dominated channels. Moreover, because we identify a clear width (and thus drainage area) dependence on the susceptibility of channels to jamming from earthflow-derived boulders, our results imply that tributary junctions are likely to mark boundaries be- tween relict topography and actively incising canyons. In other words, landslide or debris-flow-derived boulder jams in narrow channels provide an alternative explanation for the phenomenon of fluvial hanging valleys, where tributary channels in steep canyons are apparently unable to incise at the rate of trunk channel incision (Crosby et al., 2007; Wobus et al., 2006).

We note that morphodynamic models for river response to landslide inputs (Croissant et al., 2017; Ouimet et al., 2007; Shobe et al., 2016) generally assume that landslide debris is ultimately transportable by rivers. This is an assumption, however, that our results do not necessarily support. One obvious question raised by our observations therefore is how channels that are blocked with earthflow debris nevertheless manage to incise bedrock canyons over geologic timescales. While this question is not answerable with the results of this study, our observations point to two field-testable hypotheses. Central to both hypotheses is the fact that earthflows are fundamentally transient in nature and their activity must punctuate long periods of dormancy (Mackey and Roering, 2011).

We have observed epigenetic gorges (Ouimet et al., 2008) at several locations (AL3, unnamed slide between AL3 and AL2) where active earthflows impinge on Alameda Creek. This observation suggests that narrow channels in the Franciscan mélange that are buried in debris may eventually incise around the margins of boulder jams, perhaps during periods of earthflow dormancy when boulders are no longer being input into channels. Epigenetic gorge formation might be a particularly important process in the Franciscan mélange, where the clasts in the mélange, which accumulate in channels, are typically much harder than the matrix. Hence, bedrock river incision in the mélange may occur far more efficiently than boulder transport.

Alternatively, it is possible that large boulders are mobilized during extremely large but very infrequent flood events (e.g., Cook et al., 2018). In this case, during periods of earthflow dormancy, infrequent boulder transport events could result in the slow erosional removal of the valley blockage. In support of this view, we note that the knickpoint located at Oak Ridge earthflow, which is currently active, is much steeper than knickpoints located at dormant earthflows in the region (Figs. 5 and 6). This suggests that over time the valley blockages may diffuse due to sediment transport. The process of boulder transport in this scenario would likely be aided by abrasion (and hence size reduction) of boulders in place from suspended sediment (Schumm and Stevens, 1973).

Data availability. River elevation long profile and valley width data used in this study can be downloaded from https://doi.org/10.5281/zenodo.3403345 (Finnegan, 2019a).

Measured boulder size distribution data used in this study can be downloaded from https://doi.org/10.5281/zenodo.3403338 (Finnegan, 2019b). 
Earthflow displacement data used in this study can be downloaded from https://doi.org/10.5281/zenodo.3403350 (Finnegan, 2019c).

USGS data for Arroyo Hondo used in this study can be downloaded from https://waterdata.usgs.gov/nwis/inventory/?site_ no $=11173200 \&$ agency_cd=USGS (U.S. Department of the Interior/U.S. Geological Survey, 2019a).

USGS data for the Eel River used in this study can be downloaded from https://waterdata.usgs.gov/nwis/inventory/?site_ no $=11475000 \&$ agency_cd=USGS (U.S. Department of the Interior/U.S. Geological Survey, 2019b).

NASA/JPL UAVSAR data used in this study may be downloaded through their website (https://uavsar.jpl.nasa.gov/, NASA, 2019). 
Appendix A

Table A1. UAVSAR acquisitions and InSAR pairs.

\begin{tabular}{|c|c|c|c|c|c|c|c|c|}
\hline $\begin{array}{l}\text { UAVSAR } \\
\text { acquisition }\end{array}$ & 20090220 & 20091120 & 20100511 & 20100115 & 20100116 & 20111114 & 20121102 & 20130507 \\
\hline 20090220 & & $\checkmark$ & & $\checkmark$ & & & & \\
\hline 20091120 & & & $\checkmark$ & & & & & \\
\hline 20100511 & & & & & $\checkmark$ & & & \\
\hline 20100115 & & & $\checkmark$ & & & & & \\
\hline \multicolumn{9}{|l|}{20100116} \\
\hline 20111114 & & & & & & & $\checkmark$ & \\
\hline 20121102 & & & & & & & & $\checkmark$ \\
\hline
\end{tabular}


Author contributions. NF designed the study with input from JR and GB, JR supervised the mapping of landslides along the Eel River in a previous study, NF and AN performed the mapping of landslides along Arroyo Hondo and Alameda Creek, KB collected boulder size distribution data, AH processed the InSAR data, NF processed the topographic and hydrological data, and AN performed the mapping and deformation analysis of Oakridge earthflow in a previous study. All authors contributed to the writing of the paper.

Competing interests. The authors declare that they have no conflict of interest.

Acknowledgements. This work was supported by a National Science Foundation (NSF) Graduate Research Fellowship awarded to Alexander L. Nereson and the Geomorphology and Land Use Dynamics Program of NSF (EAR-1658800 and EAR-1613122 to Noah J. Finnegan). We thank Ben Brooks, Zhen Liu, and the UAVSAR flight and data processing teams for their help with acquiring and processing the data. Part of this research was sponsored by the NASA Earth Surface and Interior focus area and performed at the Jet Propulsion Laboratory, California Institute of Technology. Alexander L. Handwerger's research was supported by an appointment to the NASA Postdoctoral Program at the Jet Propulsion Laboratory, administered by Universities Space Research Association under contract with NASA. We thank the San Francisco Public Utilities Commission and Russ Fields for site access. In addition, we thank Roman DiBiase, Jeff Prancevic and Isaac Larsen for comments that improved and, in some cases, fundamentally reshaped aspects of this paper.

Financial support. This research has been supported by the National Science Foundation, Directorate for Geosciences, Division of Earth Sciences (grant nos. EAR-1658800 and EAR-1613122).

Review statement. This paper was edited by Paola Passalacqua and reviewed by Isaac Larsen and Jeffrey P. Prancevic.

\section{References}

Baum, R. L., Savage, W. Z., and Wasowski, J.: Mechanics of Earthflows, in: Proceedings of the International Conference FLOWS, Sorrento, 11-13 May 2003, Italy, 2003.

Bennett, G. L., Roering, J. J., Mackey, B. H., Handwerger, A. L., Schmidt, D. A., and Guillod, B. P.: Historic drought puts the brakes on earthflows in Northern California, Geophys. Res. Lett., 43, 5725-5731, https://doi.org/10.1002/2016GL068378, 2016a.

Bennett, G. L., Miller, S. R., Roering, J. J., and Schmidt, D. A.: Landslides, threshold slopes, and the survival of relict terrain in the wake of the Mendocino Triple Junction, Geology, 44, 363366, https://doi.org/10.1130/G37530.1, 2016b.

Booth, A. M., Hurley, R., Lamb, M. P., and Andrade, J. E.: Force chains as the link between particle and bulk friction an- gles in granular material, Geophys. Res. Lett., 41, 8862-8869, https://doi.org/10.1002/2014GL061981, 2014.

Brummer, C. J. and Montgomery, D. R.: Influence of coarse lag formation on the mechanics of sediment pulse dispersion in a mountain stream, Squire Creek, North Cascades, Washington, United States, Water Resour. Res., 42, W07412, https://doi.org/10.1029/2005WR004776, 2006.

Bull, W. B.: Stream-terrace genesis: implications for soil development, Geomorphology, 3, 351-367, https://doi.org/10.1016/0169-555X(90)90011-E, 1990.

Burbank, D. W., Leland, J., Fielding, E., Anderson, R. S., Brozovic, N., Reid, M. R., and Duncan, C.: Bedrock incision, rock uplift and threshold hillslopes in the northwestern Himalayas, Nature, 379, 505-510, https://doi.org/10.1038/379505a0, 1996.

Clark, M. K., Royden, L. H., Whipple, K. X., Burchfiel, B. C., Zhang, X., and Tang, W.: Use of a regional, relict landscape to measure vertical deformation of the eastern Tibetan Plateau, J. Geophys. Res.-Earth, 111, F03002, https://doi.org/10.1029/2005JF000294, 2006.

Cook, K. L., Turowski, J. M., and Hovius, N.: A demonstration of the importance of bedload transport for fluvial bedrock erosion and knickpoint propagation, Earth Surf. Proc. Land., 38, 683695, https://doi.org/10.1002/esp.3313, 2013.

Cook, K. L., Andermann, C., Gimbert, F., Adhikari, B. R., and Hovius, N.: Glacial lake outburst floods as drivers of fluvial erosion in the Himalaya, Science, 362, 53-57, https://doi.org/10.1126/science.aat4981, 2018.

Costa, J. E. and Schuster, R. L.: The formation and failure of natural dams, GSA Bull., 100, 1054-1068, https://doi.org/10.1130/00167606(1988)100<1054:TFAFON>2.3.CO;2, 1988.

Croissant, T., Lague, D., Steer, P., and Davy, P.: Rapid postseismic landslide evacuation boosted by dynamic river width, Nat. Geosci., 10, 680-684, https://doi.org/10.1038/ngeo3005, 2017.

Crosby, B. T., Whipple, K. X., Gasparini, N. M., and Wobus, C. W.: Formation of fluvial hanging valleys: Theory and simulation, J. Geophys. Res.-Earth, 112, F03S10, https://doi.org/10.1029/2006JF000566, 2007.

Dunne, T. and Leopold, L. B.: Water in Environmental Planning, Macmillan, New York, 1978.

Finnegan, N.: Long Profiles and Valley Width Data for Arroyo Hondo, Alameda Creek, and the Eel River [Data set], Zenodo, https://doi.org/10.5281/zenodo.3403345, 2019a.

Finnegan, N.: Earthflow-Derived Boulder Size Distributions for Arroyo Hondo and the Eel River [Data set], Zenodo, https://doi.org/10.5281/zenodo.3403338, 2019b.

Finnegan, N.: Annual Earthflow Displacement [Data set], Zenodo, https://doi.org/10.5281/zenodo.3403350, 2019c.

Fleming, R. W. and Johnson, A. M.: Structures associated with strike-slip faults that bound landslide elements, Eng. Geol., 27, 39-114, https://doi.org/10.1016/0013-7952(89)90031-8, 1989.

Gilbert, G. K.: Geology of the Henry Mountains, USGS Unnumbered Series, Government Printing Office, Washington, D.C., available at: http://pubs.er.usgs.gov/publication/70038096 (last access: 17 April 2019), 1877.

Goldstein, R. M. and Werner, C. L.: Radar interferogram filtering for geophysical applications, Geophys. Res. Lett., 4035-4038, https://doi.org/10.1029/1998GL900033, 1998. 
Golly, A., Turowski, J. M., Badoux, A., and Hovius, N.: Controls and feedbacks in the coupling of mountain channels and hillslopes, Geology, 45, 307-310, https://doi.org/10.1130/G38831.1, 2017.

Handwerger, A. L., Roering, J. J., Schmidt, D. A., and Rempel, A. W.: Kinematics of earthflows in the Northern California Coast Ranges using satellite interferometry, Geomorphology, 246, 321-333, https://doi.org/10.1016/j.geomorph.2015.06.003, 2015.

Handwerger, A. L., Huang, M.-H., Fielding, E. J., Booth, A. M., and Bürgmann, R.: A shift from drought to extreme rainfall drives a stable landslide to catastrophic failure, Sci. Rep., 9, 1569, https://doi.org/10.1038/s41598-018-38300-0, 2019a.

Handwerger, A. L., Fielding, E. J., Huang, M.-H., Bennett, G. L., Liang, C., and Schulz, W. H.: Widespread Initiation, Reactivation, and Acceleration of Landslides in the Northern California Coast Ranges due to Extreme Rainfall, J. Geophys. Res.-Earth, 124, 1782-1797, https://doi.org/10.1029/2019JF005035, 2019b.

Hungr, O., Leroueil, S., and Picarelli, L.: The Varnes classification of landslide types, an update, Landslides, 11, 167-194, https://doi.org/10.1007/s10346-013-0436-y, 2014.

Iverson, R. M. and Major, J. J.: Rainfall, ground-water flow, and seasonal movement at Minor Creek landslide, northwestern California: Physical interpretation of empirical relations, GSA Bull., 99, 579-594, https://doi.org/10.1130/00167606(1987)99<579:RGFASM>2.0.CO;2, 1987.

Keefer, D. K. and Johnson, A. M.: Earth flows; morphology, mobilization, and movement, USGS Numbered Series, U.S. G.P.O., available at: http://pubs.er.usgs.gov/publication/pp1264 (last access: 21 April 2019), 1983.

Kelsey, H. M.: Earthflows in Franciscan melange, Van Duzen River basin, California, Geology, 6, 361-364, https://doi.org/10.1130/00917613(1978)6<361:EIFMVD>2.0.CO;2, 1978.

Korup, O.: Recent research on landslide dams - a literature review with special attention to New Zealand, Prog. Phys. Geogr. Earth Environ., 26, 206-235, https://doi.org/10.1191/0309133302pp333ra, 2002.

Korup, O., Strom, A. L., and Weidinger, J. T.: Fluvial response to large rock-slope failures: Examples from the Himalayas, the Tien Shan, and the Southern Alps in New Zealand, Geomorphology, 78, 3-21, https://doi.org/10.1016/j.geomorph.2006.01.020, 2006.

Korup, O., Montgomery, D. R., and Hewitt, K.: Glacier and landslide feedbacks to topographic relief in the Himalayan syntaxes, P. Natl. Acad. Sci. USA, 107, 5317-5322, https://doi.org/10.1073/pnas.0907531107, 2010.

Larsen, I. J. and Montgomery, D. R.: Landslide erosion coupled to tectonics and river incision, Nat. Geosci., 5, 468-473, https://doi.org/10.1038/ngeo1479, 2012.

Mackey, B. H. and Roering, J. J.: Sediment yield, spatial characteristics, and the long-term evolution of active earthflows determined from airborne LiDAR and historical aerial photographs, Eel River, California, GSA Bull., 123, 1560-1576, https://doi.org/10.1130/B30306.1, 2011.

Mackey, B. H., Roering, J. J., and Lamb, M. P.: Landslide-dammed paleolake perturbs marine sedimentation and drives genetic change in anadromous fish, P. Natl. Acad. Sci. USA, 108, 1890518909, https://doi.org/10.1073/pnas.1110445108, 2011.
McLaughlin, R. J., Ellen, S. D., Blake Jr., M. C., Jayko, A. S., Irwin, W. P., Aalto, K. R., Carver, G. A., Clarke Jr., S. H., Barnes, J. B., Cecil, J. D., and Cyr, K. A.: Geology of the Cape Mendocino, Eureka, Garberville, and Southwestern Part of the Hayfork 30 x 60 Minute Quadrangles and Adjacent Offshore Area, Northern California, USGS Numbered Series, U.S. Geological Survey, available at: http://pubs.er.usgs.gov/publication/mf2336 (last access: 1 May 2019), 2000.

Mey, J., Scherler, D., Zeilinger, G., and Strecker, M. R.: Estimating the fill thickness and bedrock topography in intermontane valleys using artificial neural networks: ESTIMATING VALLEYFILL THICKNESSES, J. Geophys. Res.-Earth, 120, 1301-1320, https://doi.org/10.1002/2014JF003270, 2015.

Miller, S. R., Roering, J. J., and Schmidt, D. A.: Landslides, threshold slopes, and the survival of relict terrain in the wake of the Mendocino Triple Junction, Geology, 44, 363-366, https://doi.org/10.1130/G37530.1, 2016.

Murphy, C., Finnegan, N. J., Oberle, F. J., and Perkins, J. P.: Evidence for a Positive Feedback Between Shallow Groundwater Flow and Shear Failure in an Active Earthflow, AGU Fall Meet. Abstr., available at: http://adsabs.harvard.edu/abs/ 2018AGUFMEP24B..05M (last access: 25 April 2019), 2018.

NASA: Jet Propulsion Laboratory, California Institute of Technology, UAVSAR, Uninhabited Aerial Vehicle Synthetic Aperture Radar, available at: https://uavsar.jpl.nasa.gov/ (last access: 28 August 2018), 2019.

Nereson, A. L. and Finnegan, N. J.: Drivers of earthflow motion revealed by an $80 \mathrm{yr}$ record of displacement from Oak Ridge earthflow, Diablo Range, California, USA, GSA Bull., 131, 389-402, https://doi.org/10.1130/B32020.1, 2019.

Ouimet, W. B., Whipple, K. X., Royden, L. H., Sun, Z., and Chen, Z.: The influence of large landslides on river incision in a transient landscape: Eastern margin of the Tibetan Plateau (Sichuan, China), GSA Bull., 119, 1462-1476, https://doi.org/10.1130/B26136.1, 2007.

Ouimet, W. B., Whipple, K. X., Crosby, B. T., Johnson, J. P., and Schildgen, T. F.: Epigenetic gorges in fluvial landscapes, Earth Surf. Proc. Land., 33, 1993-2009, https://doi.org/10.1002/esp.1650, 2008.

Prancevic, J. P. and Lamb, M. P.: Particle friction angles in steep mountain channels: Friction angles in mountain channels, J. Geophys. Res.-Earth, 120, 242-259, https://doi.org/10.1002/2014JF003286, 2015.

Reneau, S. L. and Dietrich, W. E.: Erosion rates in the southern oregon coast range: Evidence for an equilibrium between hillslope erosion and sediment yield, Earth Surf. Proc. Land., 16, 307-322, https://doi.org/10.1002/esp.3290160405, 1991.

Roering, J. J., Mackey, B. H., Handwerger, A. L., Booth, A. M., Schmidt, D. A., Bennett, G. L., and Cerovski-Darriau, C.: Beyond the angle of repose: A review and synthesis of landslide processes in response to rapid uplift, Eel River, Northern California, Geomorphology, 236, 109-131, https://doi.org/10.1016/j.geomorph.2015.02.013, 2015.

Rosen, P. A., Gurrola, E., Sacco, G. F., and Zebker, H.: The InSAR scientific computing environment, EUSAR 2012, 9th European Conference on Synthetic Aperture Radar, 23-26 April 2012, Nuremberg, 730-733, 2012.

Scheingross, J. S., Minchew, B. M., Mackey, B. H., Simons, M., Lamb, M. P., and Hensley, S.: Fault-zone controls on the spa- 
tial distribution of slow-moving landslides, GSA Bull., 125, 473489, https://doi.org/10.1130/B30719.1, 2013.

Schneider, J. M., Rickenmann, D., Turowski, J. M., Schmid, B., and Kirchner, J. W.: Bed load transport in a very steep mountain stream (Riedbach, Switzerland): Measurement and prediction: BED LOAD TRANSPORT RIEDBACH, Water Resour. Res., 52, 9522-9541, https://doi.org/10.1002/2016WR019308, 2016.

Schoenbohm, L. M., Whipple, K. X., Burchfiel, B. C., and Chen, L.: Geomorphic constraints on surface uplift, exhumation, and plateau growth in the Red River region, Yunnan Province, China, GSA Bull., 116, 895-909, https://doi.org/10.1130/B25364.1, 2004.

Schuerch, P., Densmore, A. L., McArdell, B. W., and Molnar, P.: The influence of landsliding on sediment supply and channel change in a steep mountain catchment, Geomorphology, 78, 222235, https://doi.org/10.1016/j.geomorph.2006.01.025, 2006.

Schumm, S. A. and Stevens, M. A.: Abrasion in Place: A Mechanism for Rounding and Size Reduction of Coarse Sediments in Rivers, Geology, 1, 37-40, https://doi.org/10.1130/00917613(1973)1<37:AIPAMF>2.0.CO;2, 1973.

Shobe, C. M., Tucker, G. E., and Anderson, R. S.: Hillslope-derived blocks retard river incision, Geophys. Res. Lett., 43, 5070-5078, https://doi.org/10.1002/2016GL069262, 2016.

Simoni, A., Ponza, A., Picotti, V., Berti, M., and Dinelli, E.: Earthflow sediment production and Holocene sediment record in a large Apennine catchment, Geomorphology, 188, 42-53, https://doi.org/10.1016/j.geomorph.2012.12.006, 2013.

Sklar, L. S. and Dietrich, W. E.: Sediment and rock strength controls on river incision into bedrock, Geology, 29, 1087-1090, https://doi.org/10.1130/00917613(2001)029<1087:SARSCO>2.0.CO;2, 2001.

Sklar, L. S. and Dietrich, W. E.: A mechanistic model for river incision into bedrock by saltating bed load: Bedrock Incision By Saltating Bed Load, Water Resour. Res., 40, W06301, https://doi.org/10.1029/2003WR002496, 2004.

Stolle, A., Schwanghart, W., Andermann, C., Bernhardt, A., Fort, M., Jansen, J. D., Wittmann, H., Merchel, S., Rugel, G., Adhikari, B. R., and Korup, O.: Protracted river response to medieval earthquakes, Earth Surf. Proc. Land., 44, 331-341, https://doi.org/10.1002/esp.4517, 2019.
U.S. Department of the Interior/U.S. Geological Survey: NWIS Site Information for USA: Site Inventory, USGS 11173200 ARROYO HONDO NR SAN JOSE CA, available at: https://waterdata.usgs.gov/nwis/inventory/?site_no= 11173200\&agency_cd=USGS (last access: 23 July 2018), 2019a.

U.S. Department of the Interior/U.S. Geological Survey: NWIS Site Information for USA: Site Inventory, USGS 11475000 EEL R A FORT SEWARD CA, available at: https://waterdata.usgs.gov/ nwis/inventory/?site_no=11475000\&agency_cd=USGS (last access: 23 July 2018), 2019b.

Vulliet, L. and Hutter, K.: Viscous-type sliding laws for landslides, Can. Geotech. J., 25, 467-477, https://doi.org/10.1139/t88-052, 1988.

Wakabayashi, J.: Nappes, Tectonics of Oblique Plate Convergence, and Metamorphic Evolution Related to 140 Million Years of Continuous Subduction, Franciscan Complex, California, J. Geol., 100, 19-40, https://doi.org/10.1086/629569, 1992.

Whipple, K. X.: Bedrock Rivers and the Geomorphology of Active Orogens, Annu. Rev. Earth Pl. Sc., 32, 151-185, https://doi.org/10.1146/annurev.earth.32.101802.120356, 2004.

Wobus, C. W., Crosby, B. T., and Whipple, K. X.: Hanging valleys in fluvial systems: Controls on occurrence and implications for landscape evolution, J. Geophys. Res.-Earth, 111, F02017, https://doi.org/10.1029/2005JF000406, 2006.

Wolman, M. G. and Miller, J. P.: Magnitude and Frequency of Forces in Geomorphic Processes, J. Geol., 68, 54-74, https://doi.org/10.1086/626637, 1960.

Yanites, B. J., Tucker, G. E., Mueller, K. J., and Chen, Y.-G.: How rivers react to large earthquakes: Evidence from central Taiwan, Geology, 38, 639-642, https://doi.org/10.1130/G30883.1, 2010.

Zhang, X., Phillips, C., and Marden, M.: Internal deformation of a fast-moving earthflow, Raukumara Peninsula, New Zealand, Geomorphology, 4, 145-154, https://doi.org/10.1016/0169555X(91)90025-6, 1991.

Zimmermann, A., Church, M., and Hassan, M. A.: Step-pool stability: Testing the jammed state hypothesis, J. Geophys. Res.-Earth, 115, F02008, https://doi.org/10.1029/2009JF001365, 2010. 